DOI https://doi.org/10.30525/978-9934-26-184-8-14

\title{
ВПЛИВ ПОРОДНИХ ПОЄДНАНЬ НА ВІДГОДІВЕЛЬНІ ТА М'ЯСНІ ЯКОСТІ СВИНЕЙ
}

\section{Черненко О. М.}

доктор сільськогосподарських наук, професор, професор кафедри технології годівлі і розведення тварин Дніпровський держсавний аграрно-економічний університет

\section{Черненко О. I.}

кандидат сільськогосподарських наук, доцент, доиент кафедри технології годівлі і розведення тварин Дніпровський державний аграрно-економічний університет

\section{Герасимчук В. М.}

кандидат сільськогосподарських наук, заступник директора з тваринництва ТОВ «АГРОІНД» Дніпровського району Дніпропетровської області м. Дніпро, Україна

Вступ. Відомо, що за однакових господарських умов розведення окремі породи свиней та їх помісі по різному реалізують свій генетичний потенціал продуктивності та оплачують корми продукцією. Тому актуальним $є$ обгрунтування найбільш вдалих варіантів породних поєднань за іноземної інтродукції [1, с. 185; 2 , c. $30 ; 3$, c. 157$]$.

Матеріал і методика досліджень. Метою наших досліджень було з'ясувати як залежать від породних поєднань відгодівельні та м'ясні якості розведення молодняку свиней, одержаного при простому двопородному і складному трипородному промисловому схрещуванні порід данської селекції. 


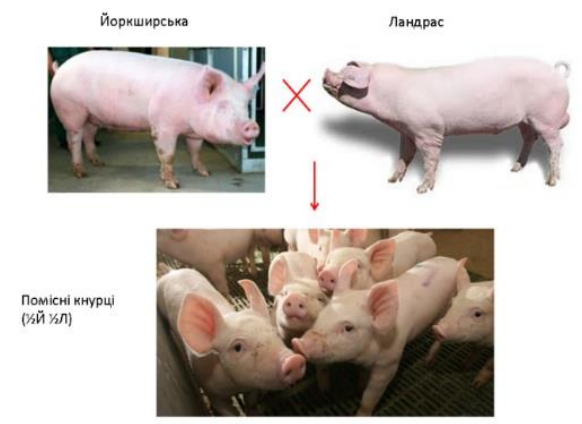

\section{Рис. 1. Схема двопородного схрещування свиноматок породи йоркшир $з$ кнурами-плідниками породи ландрас}

Згідно схеми (рис. 1) помісні кнурці 1/2Й 1/2Л спрямовуються для відгодівлі на м'ясо, а помісні свинки $1 / 2$ Й $1 / 2$ Л використовуються у подальшому трипородному схрещуванні.

Схему складного трипородного промислового схрещування представлено на рисунку 2. Згідно цієї схеми завдяки складному промисловому трипородному схрещуванню отримують фінальних гібридних поросят для відгодівлі на м'ясо: 1/4Й 1/4Л 1⁄2Д.

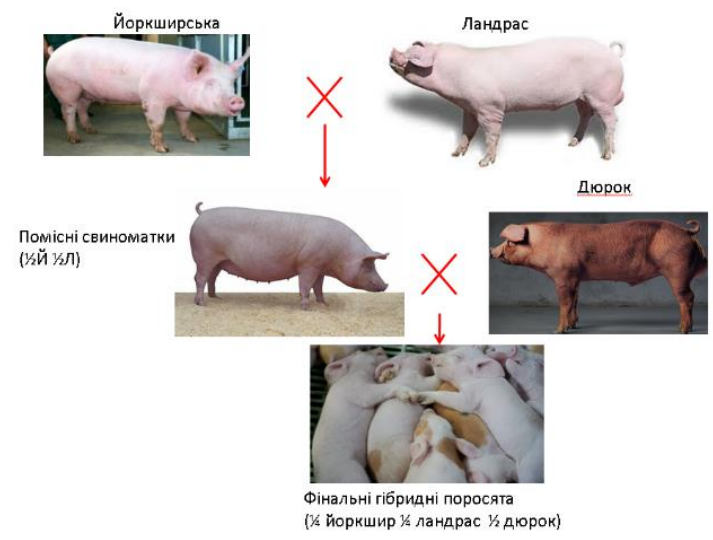

Рис. 2. Схема складного трипородного промислового схрещування 
Умови утримання свиноматок i підсисних поросят забезпечувались обладнанням, станками для опоросу, системою вентиляції, транспортування корму та годівлі, гноєвидалення у корпусі № 3 - французька фірма-виробник «I-TEК» (рис. 3).

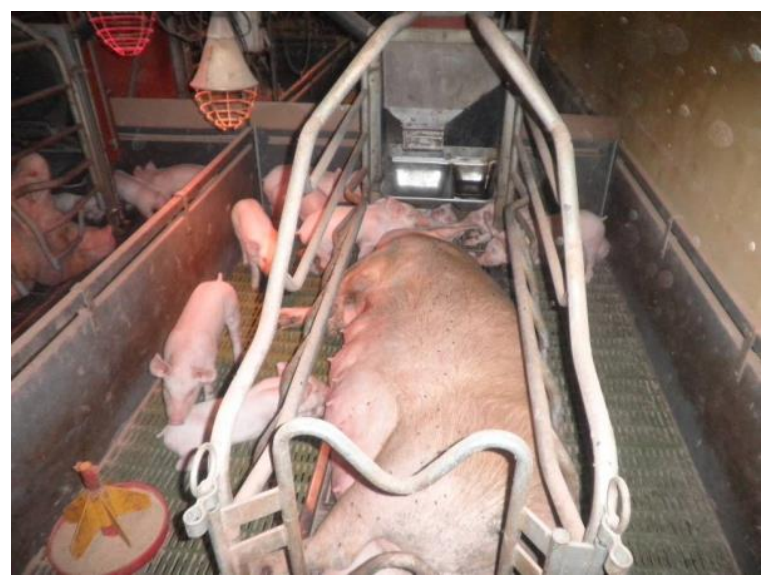

Рис. 3. Станок для опоросу свиноматок та утримання поросят-сисунів із підгодівлею у годівниці (фірма «I-TEК»)

Результати досліджень. Результати дослідження відгодівельних якостей помісних кнурців наведено у таблиці 1.

За живою масою при постановці на відгодівлю і по завершенню відгодівельного періоду суттєвих відмінностей між групами тварин не було. Середньодобові прирости живої маси за період відгодівлі (3-7 міс) найбільшими були у кнурців породних поєднань 1/4Й 1/4Л 1/2Д - 898,2 г, що більше на 45,7 г (5,4%; за $\mathrm{P}>0,999)$, порівняно 3 помісями покоління F1 1⁄2̆̆ $1 / 2$ Л. Вік досягнення живої маси 100 кг найкоротшим був у помісних кнурців $1 / 4$ Й 1/4Л 1/2Д - 168,1 діб, найдовшим - у тварин $1 / 2 \breve{И} 1 / 2$ Л 173,2 діб, міжгрупова різниця вірогідна і становить 5,1 діб (2,9\%, за Р $>0,95)$. Найменші затрати кормів на 1 кг приросту живої маси виявились у групі помісей $1 / 4$ Й $1 / 4$ Л 1/2Д - 3,27 к. од., що менше порівняно з однолітками породних поєднань $1 / 2$ Й $1 / 2$ Л на 0,18 к. од. $(5,2 \%)$ за $\mathrm{P}<0,95$. 
Таблиця 1

Результати відгодівлі помісних кнурців

\begin{tabular}{|c|c|c|}
\hline \multirow{2}{*}{ Ознака } & \multicolumn{2}{|c|}{$\begin{array}{c}\text { Покоління та породні посднання } \\
\text { піддослідних кнурців на відгодівлі }\end{array}$} \\
\hline & F1 1/2̆ $1 / 2 \Omega$ & F2 1/4 Й 1/4Л 1/2Д \\
\hline $\begin{array}{c}\text { Поставлено на відгодівлю } \\
\text { тварин, голів }\end{array}$ & 25 & 25 \\
\hline $\begin{array}{l}\text { Вік при постановці на } \\
\text { відгодівлю, днів }\end{array}$ & $90,6 \pm 2,12$ & $90,2 \pm 2,02$ \\
\hline $\begin{array}{c}\text { Жива маса при постановці } \\
\text { на відгодівлю, кг }\end{array}$ & $30,8 \pm 1,55$ & $30,2 \pm 1,74$ \\
\hline Знято з відгодівлі, голів & 25 & 25 \\
\hline $\begin{array}{c}\text { Жива маса } \\
\text { в кінці відгодівлі, кг }\end{array}$ & $100,6 \pm 3,39$ & $100,8 \pm 3,17$ \\
\hline $\begin{array}{c}\text { Середньодобовий приріст } \\
\text { (за період 3-7 місяців), г }\end{array}$ & $852,5 \pm 8,51$ & $898,2 \pm 9,2 * * *$ \\
\hline $\begin{array}{c}\text { Вік досягнення живої маси } \\
100 \text { кг, діб }\end{array}$ & $173,2 \pm 1,99$ & $168,1 \pm 1,87^{*}$ \\
\hline $\begin{array}{c}\text { Витрати корму на } 1 \text { кг } \\
\text { приросту, корм. од. }\end{array}$ & $3,45 \pm 0,097$ & $3,27 \pm 0,101$ \\
\hline
\end{tabular}

Примітка: * $\mathrm{P}>0,95 ; * * * \mathrm{P}>0,999$ при порівнянні $з$ помісними кнурцями $\mathrm{F} 1$.

М'ясні якості свиней досліджено у м'ясо-переробному підприємстві ТОВ «Рентвел», що є кампанією-партнером ТОВ «АГРОІНД». Ознаки, що характеризують післязабійні якості свиней, важливі 3 точки зору м'ясної продуктивності при реалізації продукції та $є$ результатом ефективності відгодівлі (таблиця 2).

Аналізом окремих післязабійних ознак з'ясовано, що кращими виявились показники забитих кнурців породного поєднання F2 $1 / 4$ Й 1/4Л 1/2Д. Порівняно 3 однолітками породного поєднання F1 $1 / 2 \breve{И} 1 / 2 Л$ вони швидше досягали забійної маси 110 кг на 5,5 діб $(2,9 \%)(\mathrm{P}>0,95)$, за більшої забійної маси на 6,7 кг $(9,5 \%)(\mathrm{P}<$ $0,95)$ та вищого забійного виходу на $5,9 \%$ ( $\mathrm{P}>0,999)$. 
Таблиця 2

Результати забою помісних кнурців

\begin{tabular}{|c|c|c|}
\hline \multirow[t]{2}{*}{ Ознака } & \multicolumn{2}{|c|}{$\begin{array}{c}\text { Покоління та породні } \\
\text { посднання піддослідних } \\
\text { кнурців }\end{array}$} \\
\hline & F1 $1 / 2 \breve{\mathbf{L}} 1 / 2 \Omega$ & F2 $1 / 4$ Й $1 / 4$ Л $1 / 2$ Д \\
\hline Забито тварин, голів & 5 & 5 \\
\hline Вік при забої, діб & $190,3 \pm 1,85$ & $184,8 \pm 1,74^{*}$ \\
\hline Передзабійна жива маса кнурців, кг & $104,5 \pm 3,64$ & $105,2 \pm 3,52$ \\
\hline Забійна маса (парна туша), кг & $70,2 \pm 1,85$ & $76,9 \pm 1,74^{*}$ \\
\hline Забійний вихід, \% & $67,2 \pm 0,87$ & $73,1 \pm 0,95 * * *$ \\
\hline
\end{tabular}

Примітка: * $\mathrm{P}>0,95 ;$ *** $\mathrm{P}>0,999$ при порівнянні $з$ помісними кнурцями $\mathrm{F} 1$.

Висновок. Узагальнюючи проведені дослідження ми дійшли висновку, що за відповідних умов годівлі і утримання кращими відгодівельними та м'ясними якостями характеризується молодняк свиней, отриманий від трипородного промислового

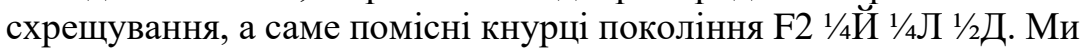
пов'язуємо встановлену перевагу їх генетичними особливостями, що під час відгодівлі виявляються у вищій енергії росту, і відповідно менших витратах кормів на 1 кг приросту та вищій скороспілості при досягненні живої маси 100 кг.

\section{Література:}

1. Волощук В.M., Баньковська І.Б., Грищенко С.М., Грищенко Н.П. Вплив умов годівлі на забійні та м'ясо-сальні якості молодняку свиней. Міжвідомчий тематичний науковий збірник. Серія «Свинарство». Полтава, 2015. Вип. 67. С. 185-190.

2. Повод М.Г. Вплив технологічних особливостей на відгодівельні показники свиней. Вісник Сумського національного аграрного університету. 2014. № 2 (25). С. 30-36.

3. Топіха В.С., Лихач В.Я., Лихач А.В. Якісні показники м'ясосальної продукції молодняку свиней породи ландрас за різних методів розведення. Вісник аграрної науки Причорномор'я. 2012. Вип. 4 (70). Т. 2. Ч. 2. С. 157-162. 